\title{
'Neither Victim nor Executioner': Essential Insights from Secularization Theory for the Revitalization of the Russian Orthodox Church in the Contemporary World
}

\author{
Rico G. Monge \\ College of Arts and Sciences, University of San Diego, San Diego, CA 92110, USA; rmonge@sandiego.edu
}

Received: 22 June 2017; Accepted: 16 August 2017; Published: 28 August 2017

\begin{abstract}
This essay explores two recent expressions of hostility towards secularization by Russian Orthodox officials (one from the Holy Synod of ROCOR and the other from Metropolitan Archbishop Hilarion Alfeyev), and evaluates the likely consequences of this hostility. Drawing from secularization theorists including Peter Berger, Jose Casanova, and Charles Taylor, as well as the thought of Albert Camus, this essay argues that the long-term health of the Russian Orthodox Church will benefit from embracing insights from secularization theorists rather than attempting to "desecularize" Russian society with state support.
\end{abstract}

Keywords: Christian; Orthodox; spirituality; theology; state; identity; human rights; Russia; persecution; secularism

\section{Introduction}

In a 2014 address to the Pontifical Theological Faculty of Southern Italy, Metropolitan Hilarion Alfeyev of the Moscow Patriarchate of the Russian Orthodox Church (hereafter ROC) asserted, "no matter what researchers say about church-state relations in Byzantium and Rus, at her very heart the Church has remained free, irrespective of the external political circumstance" (Alfeyev 2014). This lofty theological statement stands outside the reach of empirical scrutiny, as it is impossible for "researchers" to examine the inward "heart" of the Church and thus verify or falsify Alfeyev's claim. However, what can be examined is, first, that which is at stake in making such claims, and second, what quality of fruit such claims potentially bear. In the larger context of the address, which will be analyzed at length below, it becomes clear that Alfeyev wishes to neutralize any concerns about potential negative effects that might arise from increasing collaboration between the ROC and the secular nation-state known as the Russian Federation. Rather, he wishes to celebrate the dawn of a new era of freedom for Russian Orthodox Christianity, and the immense positive possibilities this era has opened up, by drawing parallels between present church-state relations in Russia and those of the Roman Empire after the Edict of Milan in 313 CE. Moreover, Alfeyev wishes to present church-state relations in Russia as a powerful antidote to Western European and North American secularization.

Following the lead of Alfeyev's address, this essay aims not to empirically analyze what is currently happening in Russia and Russian Orthodoxy. Such is the work of sociologists and historians and lies outside of my expertise ${ }^{1}$. Rather, I aim to evaluate philosophically and theologically the

1 A number of quality monographs written from these perspectives have recently appeared and are well-worth consulting. For insight into the Russian Orthodox Church's impact on Russian culture and society, see Zoe Knox's Russian Society and the Russian Church (Knox 2005). For an analysis of the effects of Russia's "forced secularization" on its contemporary religious revival, see Christopher Marsh's Religion and the State in Russia and China (Marsh 2011). Finally, for an in depth look at how the Russian Orthodox Church has affected public policy and legislation, see Irina Papkova's The Orthodox Church and Russian Politics (Papkova 2011). 
potential benefit and harm that may come to the ROC if its leadership continues to embrace the notion that a "symphony" of church and state is possible, let alone desirable. I derive the primary hermeneutics employed in this evaluation from the work of prominent secularization theorists including Peter L. Berger, Jose Casanova, Talal Asad and Charles Taylor. In doing so, I will validate many Russian criticisms of Western constructions of secularity and its concomitant consumer culture, while also identifying how and why the current models for combatting "secularization" are overly defensive reactions against the West, reactions which will likely do the ROC incalculable harm. The goal here is neither to celebrate Russia's "re-Christianization" nor to denigrate the contemporary Russian Orthodox Church as a re-imperialized pseudo-state religion. Rather, my approach mirrors that of Nicholas Berdyaev on socialism and capitalism:

A real reconciliation of East and West is impossible and inconceivable on the basis of a materialistic Communism, or of a materialistic Capitalism, or indeed of a materialistic Socialism. The third way will neither be "anti-Communist" nor "anti-Capitalist". It will recognize the truth in liberal democracy, and it will equally recognize the truth in Communism. A critique of Communism and Marxism does not entail an enmity towards Soviet Russia, just as a critique of liberal democracy does not entail enmity towards the west (Berdyaev 1949, p. 80).

Just as Berdyaev looks for an affirmative third way that avoids reactionary dualistic constructions, I seek to employ insights from secularization theorists to illuminate a dialectic of victim mentality and triumphalism present in two contemporary Russian Orthodox statements, one from the aforementioned Metropolitan Hilarion Alfeyev and another from the governing synod of the Russian Orthodox Church Outside Russia (hereafter ROCOR). What I aim to suggest is that the Russian Orthodox Church as a whole will best achieve the freedom and flourishing it seeks by embracing more nuanced understandings of secularization rather than fleeing from what it perceives to be secularization as such. To accomplish this end, this essay will proceed in four distinct sections: the first section will set forth a working definition of the terms "secular" and "secularization"; the second section will analyze and evaluate ROCOR's recent official statement on the Russian Revolution of 1917 and its implicit rejection of all secularization; the third section will engage with Alfeyev's critique of Western secularism in which he favorably compares the era of the Edict of Milan to the present state of affairs in Russia, arguing that both together represent a superior model for church-state interaction than that of Western secularization; and the fourth section will glean insights from secularization theorists in order to not only shed light on valid Russian Orthodox concerns about "the West," but also to demonstrate how current ROC and ROCOR attitudes towards church-state relations are likely to harm the health of Russian Orthodoxy in the long term. The essay will conclude by proposing the mentality the Church must adopt towards all state relations if it is to fulfill its prophetic mission to the world.

\section{Defining "Secular" and "Secularization"}

Like any term, the words "secular" and "secularization" have a range of meanings and any attempt to claim, "this is what this word really means" is linguistically naïve. Indeed, defining "the secular" has proven so contentious that some have advocated abandoning use of the term altogether (Berger 1990, p. 106). Such approaches are not helpful; rather, careful examination of the way these terms have been historically used can play an invaluable role in illuminating what is at stake for individuals and communities when they take stances in for or against what they understand these terms to signify. Furthermore, by setting forth a working definition one can gain hermeneutic tools that facilitate productive ways in which to interpret complex phenomena. For these reasons, I employ the definitions laid down by one of the foundational figures of secularization theory, Peter L. Berger for this article.

In his landmark work, The Sacred Canopy, Berger observes that these terms were first used in a morally neutral mode in Western Europe to describe both intra-ecclesial realities and also the transfer 
of property away from church authority. In the former case, regular clergy designated those who followed a monastic rule (regula), whereas secular clergy were those who operated in "the world" outside of the confines of a monastery and outside of a monastic rule of obedience. In the latter case, "secularization" referred to the byproduct of Protestant-Catholic warfare, in which lands under ecclesial authority were transferred to state authorities or private citizens. Over time, however, the terms have come to take on "highly charged" moral valences depending on whether those using these words are sympathetic or hostile to religion. As Berger puts it, "in anti-clerical and 'progressive' circles it has come to stand for the liberation of modern man from religious tutelage, while in circles connected with the traditional churches it has been attacked as 'de-Christianization,' 'paganization,' and the like" (Berger 1990, p. 106). As we shall see below, much Russian Orthodox discourse defines secularization in precisely these ways. It is thus used both to denigrate the hegemony of Western Enlightenment liberal democracy and its perceived freedom from the shackles of religion ${ }^{2}$, while also equating secularism with anti-Christian hostility and moral libertinism. On the flip side, there are Christian thinkers in Europe and America who have championed secularization (and by this they mean secular humanism) as the evidence that Euro-American culture has positively appropriated Christian values in a way that no longer requires acceptance of institutional Christianity, let alone belief in God. Harvey Cox, Gabriel Vahanian, and Thomas J.J. Altizer have each in their own way hailed secular humanism as Christianity's natural triumphant enculturation (Cox 2013; Vahanian 2008; Altizer 2002) ${ }^{3}$.

Berger's working definition of secularization, however, eschews moral valuations in order to describe the phenomenon itself and to identify and elucidate the mechanisms by which secularization progresses. Thus he defines secularization as "the process by which sectors of society and culture are removed from the domination of religious institutions and symbols" (Berger 1990, p. 107). Careful attention to Berger's language is key. He does not assert that religious institutions and symbols no longer have any place in a secularized society; rather, he indicates that a secular society is one in which religion is $a$ voice in the public sphere, but no longer the voice in the public sphere. Or, as Jeffrey Stout has put it, discourse in the public sphere is no longer framed by "a single theological perspective ... shared by all ... interlocutors" (Stout 2004, p. 97). A hallmark of this removal of domination is the separation of church and state, which, again, does not mean that religious voices are to be excluded from political discourse. Instead, they no longer control the discourse nor do they unilaterally dictate policy-making. Beyond the political sphere, secularization "affects the totality of cultural life and of ideation, and may be observed in the decline of religious contents in the arts, in philosophy, in literature and, most important of all, in the rise of science as an autonomous, thoroughly secular perspective on the world" (Berger 1990, p. 107). As with politics, this does not mean that religion is excluded from the realms of art, philosophy, literature and science. Instead, art no longer is compelled to focus on religious themes in order to be considered valid, philosophy no longer is constrained to develop systems of thought that reinforce the dominant religious ideology, literature is no longer merely a conduit for expressing religious values in poetic forms, and science is no longer pressured to keep its findings in line with religious narratives concerning the cosmos. Nevertheless, in a secular society (according to Berger's definition), religion may continue to have a "seat at the table" in inspiring the arts and literature and in guiding philosophical and scientific inquiry. It simply is no longer allowed to control them.

2 Cf. the Enlightenment-based political ideals of Immanuel Kant, David Hume, John Locke, Jean-Jacques Rousseau, and Thomas Hobbes, among others (Kant 2016; Hume 1990, 2016; Locke 1988; Rousseau 2009; Hobbes 1996).

3 Cox, Vahanian and Altizer are all influenced by Friedrich Nietzsche's overall philosophy and critique of culture, including the proclamation of the "death of God." Their positive valuation of the secular rests in their essential agreement with Nietzsche's statement that "if they [secular atheist humanists of England] consequently think they no longer have need of Christianity as a guarantee of morality; that is merely the consequence of the ascendancy of Christian evaluation and an expression of the strength and depth of this ascendancy" (Nietzsche 1990, p. 81). 


\section{Resentment and Triumphalism in ROCOR's Epistle on the Bolshevik Revolution}

While the majority of Russian Orthodox clerics were strikingly silent on the 100th anniversary of the Bolshevik Revolution, the semi-autonomous governing synod of ROCOR spoke out emphatically in its "Epistle of the Synod of Bishops of the Russian Orthodox Church Outside of Russia on the 100th Anniversary of the Tragic Revolution in Russia and Beginning of the Godless Persecutions"4 . ROCOR's epistle is unsurprisingly vitriolic in its tone given this ecclesial jurisdiction's tumultuous history. After 1927, ROCOR broke communion with the ROC due to the latter's agreement to submit to the demands of the Soviet government. Communion between the two churches was not restored until 2007. Thus, unlike the ROC, ROCOR never came to accept any legitimacy to the Soviet state and, moreover, preserves to this day a sensibility that stands firmly against even Berger's aforementioned morally neutral definition of secularization. As we shall see, ROCOR's epistle not only rejects the separation of church and state, it argues that Russian Orthodoxy ought to wield power over Russian culture by eradicating all cultural symbols of Russia's Soviet cultural past. The point here is not to condemn these attitudes; indeed, they are completely understandable responses to the atrocities of Vladimir Lenin and Josef Stalin. Hence, the epistle calls on the Russian people to "rid Red Square of the remains of the main persecutor and executioner of the 20th century [Lenin]," and to destroy the monuments to him as "symbols of catastrophe, tragedy, and of the destruction of our God-given Sovereignty" (Synod of Bishops 2017). Given Lenin's role as a principal architect of the mass killings known as the "Red Terror," ROCOR's request is quite compelling 5 .

ROCOR's demand that Lenin's tomb and monuments be destroyed, however, becomes more problematic when one considers the rationale given for doing so ${ }^{6}$. Instead of invoking concepts like "human rights," "war crimes," or "political genocide,"-concepts that have cross-cultural and interreligious/irreligious currency-ROCOR argues that the Russian state must do this in order to repent of its "rejection of the Divinely-ordained [Tsarist] government" and thereby enact a "symbol of reconciliation of the Russian nation with the Lord." This theological imperative also requires returning the names of all cities, oblasts (provinces), and streets to their "historic" Christian names. Ultimately, ROCOR concludes that nothing less than a total rejection of secularization will suffice, arguing that "every Russian person" should "come to the conclusion that in his God-preserved nation, there is no place for the symbols of the godless state and the names of militant atheists" (Synod of Bishops 2017). ROCOR's theo-political vision thus reveals two significant difficulties: first, a belief that the Russian state must again become Christianized to the degree that there is no room for activist dissent, and second, an unexamined assumption that a state can genuinely be anything but godless. Put differently, ROCOR asserts an unaltered faith in the Byzantine model of symphonia between church and state as the only proper way for the Orthodox Church to function ${ }^{7}$.

Why is symphonia necessary on a practical level for ROCOR? While the reasons are too numerous to recount here, the Epistle itself reveals one key geopolitical component-a deep resentment towards Western imperialism and Western secularization. There is a deeply rooted belief that only if the Russian Church and Russian State speak as one can they stand up against these oppressive external powers effectively. Again, it should be stressed that this resentment does have a certain degree of

4 Since 2007, ROCOR is "semi-autonomous" in that it is officially a part of the Moscow Patriarchate, but holds ecclesiastical jurisdiction over the majority of Russian Orthodox Churches in Western Europe, the United States, Canada, Latin America, Australia and New Zealand. Its headquarters are in New York City.

5 For a detailed account of the ideology and atrocities of the "Red Terror," see Lenin's Terror (Ryan 2012).

6 See activist and lawyer Lena Zezulin's critique of ROCOR's Epistle for a brief but similar appraisal to the one I offer here (Zezulin 2017).

7 Symphonia is the Byzantine political theory that church and state can and should operate in harmony with each other, with neither side dominating the other. After the fall of Constantinople (aka 2nd Rome) and its Caesars, Russians came to understand Moscow as 3rd Rome, and the rulers of the Russian Empire took over the title of Caesar (Tsar), thus continuing the ideal of symphonia. See An Examination of Church-State Relations in the Byzantine and Russian Empires With an Emphasis on Ideology and Models of Interaction, (Gvosdev 2001). 
legitimacy, and is shared by many Russians who are of different faith traditions than Eastern Orthodox Christianity ${ }^{8}$. No doubt referring to the increasing hostilities the United States and its NATO allies are currently fomenting against Russia, ROCOR states, "it is important to note that the constant denigration of Russia on the part of 'Western civilization' we see today existed a hundred years ago and, in fact, much earlier. The world despised the Russian Empire, the heir to Holy Orthodox Rus" (Synod of Bishops 2017). This resentment towards the hypocrisy and abusiveness of the United States and NATO is, quite arguably, well founded. Ironically, this very hypocrisy and abusiveness has been documented extensively by a number of American secular humanist intellectuals ${ }^{9}$.

For ROCOR, symphonia is also deeply practical, because the Russian Revolution and all of its accompanying horrors stem directly from the rejection of symphonia. Widespread poverty, corruption in the royal family, Tsar Nicholas II's debilitation of Russia through the Russo-Japanese War (1904-1905), and the failures of the ROC and the Russian Imperial State to address these and other pressing issues are rejected categorically as non-contributing factors lest culpability fall upon anyone but the revolutionaries themselves. "We must not," continues the Epistle, "under any circumstances justify the actions of those responsible for the deadly revolution." The blame instead rests firmly on the shoulders of those who "neglect[ed] faith in Christ" and who rejected "the Divinely-ordained government." Quoting St. Markary Nevsky, ROCOR makes clear their belief that the primary (perhaps sole) problem was "blasphemy against God and plots against his anointed one [the Tsar]" (Synod of Bishops 2017). Given that "anointed one" is the equivalent of the Hebrew term "Messiah" (and its corresponding Greek term "Christos"), such assertions can sound like wantonly blasphemous attributions of "messianicity" to the Emperor. However problematic this doctrine may be, these statements can be fully understood only if one understands that Byzantine symphonia maintained that the Church's role was to manifest the Priesthood of Christ in the world, while the anointed Emperor was to manifest the Kingship of Christ. According to Eusebius, monarchy and not democracy was God's approved political system, and thus the Christian Emperor was the "friend of God" who possessed a "sacred kingship," was God's conqueror of the enemies of the faith through "usages of war," and was the "interpreter of the Word of God" (Eusebius 2005). While Eusebius's ideas clearly were novel (Christianity thrived for its first 300 years without an emperor), and although his ideas were never dogmatized, they became ingrained in Byzantine culture and its Russian inheritors. Understood contextually, while ROCOR's position has no firm theological grounding, it is nevertheless true that they are adhering faithfully to a 1700 year-old trajectory of Orthodox political thought.

This faithful adherence to symphonia in turn creates two major problems that will be revisited below in light of contemporary secularization theory. First, ROCOR has consistently conflated political martyrdom with martyrdom for the faith, which is directly related to their conflation of church and state. Accordingly, they assert that the Revolution brought about the "martyric death of the Tsar himself and his most August family." But how, one might ask, were their deaths "martyric"? They were not killed for their faith. They were not told to renounce Jesus Christ or be executed, as the early Christian martyrs prior to the Edict of Milan were. They were killed for their social class, their crimes (real or

8 Indeed, at the same meeting with Putin in which Patriarch Kirill, primate of the ROC, referred to Putin's rule as "a miracle of God," two prominent Muslim leaders in Russia also expressed their support. Mufti Ravil Gainutdin told Putin, "Muslims know you, Muslims trust you, Muslims are wishing you success," while Mufti Ismail Berdiyev explained further, "You are the only person who has shown the United States its place" (Bryanski 2012).

9 Consider, for example, how the United States and its allies relentlessly have criticized Russian legislation against "promotion of homosexuality," to the point of even entertaining the idea of boycotting the Sochi Winter Olympics of 2014, while, at the same time, turning a blind eye to Middle-Eastern allies such as Saudi Arabia where homosexuality is punishable by death. Also relevant is the blatant hypocrisy of American accusations against Russia for "hacking" the 2016 American Presidential election, when the United States has a record of meddling in countless democratic elections across the world since the end of World War II. See, for example, On Western Terrorism (Chomsky and Vltcheck 2013), Hegemony or Survival (Chomsky 2003), Empire's Workshop (Grandin 2007), Exposing the Lies of Empire (Vltchek 2015) and The Shock Doctrine: The Rise of Disaster Capitalism (Klein 2008). 
perceived) against the Russian people, and their politics ${ }^{10}$. Referring to the majority of the Romanov family as Christian martyrs makes sense only if one interprets the death of Tsar Nicholas II (and the royal family) as the assassination of the "friend of God" and "sacred king." Crucial here, is that deeming Nicholas II's death as martyric, vitiates the power of the canonization of Grand Duchess Elizabeth Romanov (St. Elizabeth the New Martyr). Elizabeth forgave the revolutionary who murdered her husband (and pleaded for his life to be spared), then renounced her wealth and royal status and became a nun, and worked tirelessly for the next 13 years of her life to alleviate the sufferings of the poor and oppressed. The implications of the sharp differences between Grand Duchess Elizabeth and Tsar Nicholas II will become all the more significant in light of the insights of secularization theory.

The second major problem created by ROCOR's absolutist insistence on symphonia revolves around its accusation that "the educated classes in Russia, raised in so-called "Westernizing" traditions, pushed Russia with almost suicidal relentlessness into the abyss, pushing the Russian people in every way possible to reject their faith, their Tsar and their Fatherland" (Synod of Bishops 2017). Again we see that ROCOR sees Orthodox Christianity, the Tsar, and the Russian State as inextricably linked, which in turn inhibits thoughtful reflection on why these things happened. While ROCOR's description here is largely accurate, it fails to ask crucial questions that secularization theory will help illuminate. Why did the educated classes come to reject these concepts? And what do we make of the countless Russian Orthodox theologians, philosophers, writers, and artists who remained committed to the Orthodox faith but rejected Tsarism and statist nationalism ${ }^{11}$ ?

\section{Freedom, Anti-Secularization and Metropolitan Hilarion Alfeyev}

Unlike ROCOR's epistle, Metropolitan Hilarion Alfeyev's address to the Pontifical Theological Faculty avoids both triumphalism and overt nostalgia for Russia's tsarist heritage. Instead, Alfeyev's address consists of three major (and interrelated) claims worthy of analysis and evaluation: (1) a critique of the West and its apotheosis of "liberal democracy"; (2) a defense of the concept of "symphonia"; and (3) a reading of Constantine's Edict of Milan as parallel to the contemporary situation in Russia under the governance of Vladimir Putin. As we will see below, secularization theory will validate important aspects of Alfeyev's critique of the West, while also providing important crucial warnings concerning the likely outcomes that will result from a wholesale embrace of symphonia and the Edict of Milan which ushered in this era in ancient Christianity.

Alfeyev's critique of the West itself consists of two main assertions, which, at first glance seem to contradict each other. On the one hand, Alfeyev is concerned that Western liberal democracies are themselves becoming increasingly totalitarian, while, on the other, he believes that they are decaying into an ethos of libertine amorality. Close attention to his argument, however, reveals a cohesive (if not entirely persuasive) thesis. In short, Alfeyev maintains that Western liberal democracies are increasingly limiting the freedom of their own populaces and exerting dominance over non-Western countries and cultures, while concealing this dominance through the ideal of a freedom that constitutes little more than freedom from all forms of traditional morality. In this regard, Alfeyev's concerns are not far from Charles DeGaulle's, who was deeply concerned about "the American will to power cloaked in idealism." Alfeyev links the present situation in Europe and America to the pre-Constantinian Roman Empire, arguing that what "is happening today in the West is the gradual restoration of the Pax Romana, of global international hegemony." Secularization is thus, for Alfeyev, the liberation of

10 During the "Red Terror," for example, religion played little to no role in determining who should be executed. Martin Latsis, high ranking official of the Bolshevik police (the Cheka) instructed his subordinates, "Do not look in materials you have gathered for evidence that a suspect acted or spoke against the Soviet authorities. The first question you should ask him is what class he belongs to, what is his origin, education, profession. These questions should determine his fate. This is the essence of the Red Terror" (Tolczyk 1999, p. 19).

11 I have here in mind Fyodor Dostoevsky, Vladimir Soloviev, Wassily Kandinsky, Nicholas Berdyaev, Alexei Khomiakov, Maria Skobtsova (St. Maria of Paris) and, although he ultimately charted his own path outside the official confines of the Orthodox Church, Leo Tolstoy. 
the modern liberal democratic state from the checks to its power that Christianity has to offer, for the removal of state power from religious influence "has in reality released ... the European super-state, which is the cultural heir of the Roman Empire, a colossal energy of subjugation to authority." His most forceful assertion along these lines, which resonates strongly with the concerns of Western intellectuals from Noam Chomsky to Glenn Greenwald, is based on the ever-growing power of the security state and its burgeoning surveillance apparatus ${ }^{12}$. He describes the "burning energy" of the security state thus:

This burning energy today aims to break completely with Christianity which has restrained its totalitarian impulses for seventeen centuries. As a result this energy unconsciously strives towards the establishment of an absolute dictatorship, which will demand the establishment of complete control over every member of society. Is this not where we are heading for 'in the interests of security' in agreeing to the obligatory introduction of electronic passports, of universal fingerprinting and the ubiquitous presence of closed-circuit television cameras? After all, this can be used for other purposes which can also be ascribed to 'strengthening security measures (Alfeyev 2014).

While Alfeyev's claim that post-Constantinian Christianity restrained the totalitarian impulses of nation-states is beyond dubious, we shall see below that his core concern that Christianity bears within it the potential to resist totalitarianism resonates heavily with the thesis of Jose Casanova regarding the place of religion in today's public sphere.

The second part of Alfeyev's claim, that the only freedom guaranteed in modern Western nation states is freedom from morality, begins to reveal that Alfeyev's ideal model for church-state interaction is itself a restoration of symphonia, which has been historically far more totalitarian than Alfeyev wishes to admit. Further developing his linkage of the pre-Constantinian Roman Empire with Western liberal democracies, Alfeyev ultimately makes the highly unsubstantiated claim that the latter are worse than the former. Accordingly, he contends that the Roman Empire was largely indifferent towards immorality, while modern democracies are concerned with promoting immorality as normative. Alfeyev's primary problem with both the Romans and the modern democratic state is that religion is reduced to a tool that bolsters state power. As he puts it,

The modern-day democratic state is even viewed by some as the role of guarantor of the legal status of immorality, for it protects citizens from the encroachments of 'religious sanctimoniousness.' The role of religion, as in Rome, is seen in an exclusively utilitarian light-it is the servant of the state without any claims to truth, the 'personal affair of each individual.' And yet the state must be recognized unconditionally and we must obey its laws, including those that undermine its foundations (Alfeyev 2014).

According to Alfeyev, therefore, the pre-Constantinian Roman Empire and the modern liberal democratic state each desire absolute power, protecting their citizens only from having to be subject to religiously defined moral norms. For this reason, Alfeyev sees the great contribution of Constantine to be the creation of a new space in which symphonia between Church and state "allowed the Church fully to reveal herself in her ministry to thousands of people, to realize her gracious gifts in history, to exert an influence on the formation of many cultures and traditions" (Alfeyev 2014). It is this "greatest merit of Constantine" that Alfeyev argues is being reduplicated in Vladimir Putin's Russia.

Alfeyev's endorsement of symphonia ultimately reveals that he defines ecclesiastical freedom primarily in terms of the Church's freedom to exert influence over the state. Furthermore, the "secularization" that he opposes is not the official separation of powers (as in Berger's definition), but

12 In addition to the aforementioned works of Chomsky, Vltchek, and Grandin, see Greenwald's No Place to Hide: Edward Snowden, the NSA, and the U.S. Surveillance State (Greenwald 2014). 
any situation in which the state increases its power and wields this power over the Church. Hence, he does not romanticize the entire Tsarist era of Russian Orthodoxy, noting that "with the abolition of the Patriarchate [under Tsar Peter the Great] and the setting up in 1721 of the Holy Ruling Synod ... there began the period of secularization and the subjugation of the Church to the state" (Alfeyev 2014). For Alfeyev, the Church must neither merge with the state, nor become subject to it, nor serve the state in a utilitarian way that increases state power. Rather, the Church must be free to exert a transformative influence over state and society.

As already noted, Alfeyev takes the perfect model for this interaction to be the post-Constantinian era ushered in by the Edict of Milan, and he claims that this is again the current model for interaction in Russia. The Edict of Milan ushered in "a golden age of Christianity" during which, according to Alfeyev's selective narrative, "influenced the renewal of all of society's institutions, gave a new integral foundation to family relationships and the attitude towards women, and ensured the gradual eradication of the institution of slavery in the empire" (Alfeyev 2014). Focusing only on these arguably positive influences, Alfeyev contends that ecclesial power "upon entering the structure of state power, did not merge with it," but was the primary catalyst for the positive transformation of European society. These developments are so thoroughly sacrosanct in Alfeyev's understanding, that the rejection of symphonia "would spell the death of civilization for our continent." Fortunately, this has not yet become the case, for "today the Church and state in Russia, as well as in some countries in the post-Soviet expanse, are able to speak with a single voice and express a united position," while at the same time the "principle of mutual non-interference of Church and state in the internal affairs of each other must be preserved and is being preserved" (Alfeyev 2014). In short, a new "golden age of Christianity" is being reborn in Russia and other post-Soviet states, because the spirit of the Edict of Milan has itself been reborn in these nation states ${ }^{13}$.

\section{The Edict of Milan: Edict of Toleration or Edict Increasing State Power?}

In light of these bold claims, we must ask whether Alfeyev's interpretation of the Edict of Milan (and its long-term social and political consequences) is compelling or even tenable. In Alfeyev's reading, the Edict of Milan "in essence recognized the fact that the Church is not some marginal sect that corrupted the traditional pillars of society. On the contrary, the document's authors were convinced that Christians were capable of directing the mercy of God to all the people." In other words, the Edict was a recognition by Constantine (and the other officials who drafted it) of the value of Christianity and its ability to bring transformative grace to all of Roman society, revitalizing its morality. Through this peculiarly idealistic lens, Alfeyev asserts, "it is precisely this moral potential, rooted within the free human person, that the emperor Constantine saw in Christianity when he allowed this powerful positive creative energy to be released and act upon all of society." Because of his emphasis on the "free human person," Alfeyev is careful to differentiate Constantine's Edict of Milan from Theodosius I's Edict of Thessalonica (380 CE), "which proclaimed Christianity to be a state religion and placed the traditional pagan religion in effect outside of the law." The Edict of Milan thus represents a "golden age" because it preserves the freedom of the individual person, while also opening up the space through which Roman society was permanently transformed and morally improved. Moreover, it is the Edict of Milan that "opened a new page in the life of the Roman Empire: it determined the

13 Hence Alfeyev explicitly states, "Something similar to what happened in the Roman Empire in 313 took place twenty six years ago within the then Soviet Union. We were witnesses to how the Church in our country, after many trails and bloody victims, suddenly came out of the ghetto, rose up from her knees and began her triumphant march through the cities and villages. A significant part of society again discovered its Christian identity." Reinforcing the idea that these developments are unequivocally positive, he goes on to state that "certain events in the Church's history cannot be explained other than as a divine miracle. Such a miracle was the era following the Edict of Milan in 313. No less a miracle happened in our country at the end of the 1980s. Could people, who only a few years before this risked their welfare for their faith, and in some instances their lives too, evaluate the freedom that had unexpectedly fallen on their heads as anything other than a divine miracle?" (Alfeyev 2014). 
paradigm of the development of church-state relations in the countries that came into being after its collapse or under its cultural influence" (Alfeyev 2014).

There are three main problems with Alfeyev's triumphalistic interpretation of the Edict of Milan. First, the text of the Edict of Milan itself reveals that its aims were to increase state power and potentially resurrect the Pax Romana, not bring about the transformation of the Roman society and its morals. Second, the "golden age of Christianity" to which Alfeyev refers is not possible to ascribe to the era of the Edict of Milan in a way that remains separable from the Edict of Thessalonica, the sixth-century code of Justinian, and the fusion of Church-state power that occurred in Medieval Western Europe. Finally, Alfeyev's complaints against the contemporary West reveal that he yearns not for the era of the Edict of Milan and its tolerance, but rather for the post-Theodosian and post-Justinian eras of extensive Christian hegemony over all aspects of social life.

In order to understand how the Edict of Milan was intended to increase state power, it is necessary to recall the main reasons given for the persecution of Christians in the first place. According to Tertullian (c. 155-c. 240 CE), Christians were frequently scapegoated by the Romans for not submitting to the imperial cult and thus becoming "the cause of every public defeat and every misfortune of the people. If the Tiber rises to the city walls, if the Nile does not rise to the fields, if the sky stays the same, if the earth moves, if there is a famine, a plague, straightaway the cry is heard, "The Christians to the lions!'” (Tertullian Apologeticum 40, ANF 3:47). Tertullian's claim makes sense only if one understands that from the reign of Augustus (27 BCE-14 CE), the Roman imperial religion had come to consist of "religious festivals [which] proclaimed the 'good news' (euangelion) of the deified emperor, who, as savior or son of God, had brought peace, faith, and justice into the world. Assuming the highest priestly office, that of pontifex maximus, the emperor himself became a divine being in Roman imperial religion" (Chidester 2000, p. 5). Because Christians refused to participate in these festivals and to offer incense to the deified emperor, their refusals were seen not only as subversive to the values of the state and of Roman society, but also as potentially awakening the ire of the very gods that protected the Roman Empire. Accordingly, "Christian rejection of the gods registered as an attack on the city. In these terms, Christians were charged with committing crimes not only against the gods, but also against society" (Chidester 2000, p. 75). Christians were dangerous "atheists," who were weakening the state by causing both natural and supernatural dissention.

If the Edict of Milan were merely about promoting "tolerance" of these dangerous Christian dissidents, it would have been an unnecessary proclamation, for the Edict of Toleration by Emperor Galerius in 311 CE had already made Christianity a legal religion and ended the persecution of Christians throughout the Empire. Mere toleration, however, is not the same as affirmation, or, a fortiori appropriation. Hence, two years later the Edict of Milan was promulgated by Constantine with language that indicates a clear intent to increase state power and reclaim the Pax Romana, which had disintegrated nearly a century earlier. The text of the Edict thus clearly states that "we ... grant to the Christians and others full authority to observe that religion which each preferred; whence any Divinity whatsoever in the seat of the heavens may be propitious and kindly disposed to us and all who are placed under our rule" (Edict of Milan 313). Christians were no longer merely to be tolerated as harmless pseudo-subversives; they were to receive full inclusion so that their God might too become one of the protectors of the Empire, who "may show in all things His usual favor and benevolence." Finally, the Edict makes clear that other religions have previously been granted full inclusion "for the sake of the peace of our times," and that extending this full inclusion to Christians will create a more powerful, stable state that is more fully equipped to resurrect some semblance of the Pax Romana. Ironic, then, are Alfeyev's claims that it is only Western liberal democracies that wish to increase their 
power and enforce a new Pax Romana, when the very text of the Edict of Milan indicates that it was promulgated in order to achieve these same aims ${ }^{14}$.

Even more problematic than Alfeyev's misreading of the purpose of the Edict of Milan, however, is the manner in which he claims that the era that it ushered in was the "golden age of Christianity." Whether intentional or not, by making this claim, Alfeyev subtly elides the era of the Edict of Milan (313-379 CE) with Theodosius's Edict of Thessalonica (making Christianity the official religion of the Roman Empire), and the Code of Justinian (compiled between 528-529 CE). For if Alfeyev truly means to focus only on the period between 313 and 379, six of the seven Ecumenical Councils of the Orthodox Churches would be excluded. Moreover, the great cultural achievements he extols in the arts, politics, and culture all come after Theodosius and Justinian. Byzantine iconography and music, the architectural marvels of the Hagia Sophia, and the encoding of Christian morality in civil law, all of which are implied by Alfeyev's phrase "golden age" occur long after Christianity achieves mere acceptance within the Empire.

The stakes are high in this subtle elision of eras, for Alfeyev has also stated that this is the new era of Russian church-state interaction. For in the codes of Theodosius and Justinian we find that the formerly persecuted have become the persecutors. In the Theodosian laws of the late 4th century, for example, we find, enshrined in law, instructions for the punishment of those deemed to be Christian heretics (including heavy fines), orders to close all pagan temples and to execute those who continue to practice pagan temple sacrifices, the abrogation of property rights for those who convert from Christianity to paganism, and protocols for fining and publicly shaming those who profess the Manichaean religion (Theodosius 1997). Under Justinian, such regulations were intensified. Justinian closed the Academy of Plato and Aristotle, and left only one religion, Judaism, with legal status besides non-heretical Christianity. However, Judaism itself was subject to standards set forth by Justinian's laws. Jews were allowed to gather and read their "Sacred Scriptures" in Hebrew, but could do so only if Greek or Latin were also used so that the average citizen could understand and scrutinize what was being read and taught. This was to ensure that "there shall be no opportunity for their interpreters, who make use only of the Hebrew, to corrupt it in any way they like, since the ignorance of the public conceals their depravity." Reading of the Mishnah was prohibited entirely, and Jewish congregations were only considered valid if they taught that there was a resurrection of the dead. Put differently, the Byzantine state made itself the arbiter of what constituted "true Judaism" both in terms of orthodoxy and orthopraxy (Justinian 1998).

Is too much being made here of Alfeyev's elision of the era of Milan with that which came later through the use of the term "golden age"? It seems that one could charitably grant that perhaps he was simply using sloppy or imprecise language. However, his complaints against what he perceives to be the menace of secularization demonstrate otherwise. Pro-LGBT billboards in England, an "all is permitted attitude" he alleges to be characteristic of the West, and the infamous Pussy Riot incident at Christ the Savior Cathedral in Moscow, are all evidence of a rising "totalitarian freedom." This "totalitarian freedom, based on human passions," threatens to "return us to the times of the pagans" and "instead of respect for the feelings of other people, it preaches an all-is-permitted attitude, ignoring the beliefs and values of the majority" (Alfeyev 2014) ${ }^{15}$. Yet in each of these cases, Western security states teetering towards totalitarianism are not enforcing libertinism and suppressing dissent; rather, private citizens are voicing their opinions in the public sphere with differing levels of intensity. However intensely private citizens may be voicing their opinions, one is left wondering

14 For an excellent collection of recent essays on the legacy of Constantine's Edict, see Christianity, Democracy, and the Shadow of Constantine (Demacopoulos and Papanikolaou 2016).

15 The "Pussy Riot Incident" is a particularly complex issue as it was, on the one hand, an act of protest against government and ecclesiastical corruption, and, on the other hand, an act of trespass in private sacred space that was deemed highly offensive by much of the Russian populace. For nuanced and competing assessments of what was at stake in Pussy Riot's act of protest see both "An Appeal to Mary: An Analysis of Pussy Riot's Punk Performance in Moscow" (Denysenko 2013), and "Women on the Fault Lines of Faith: Pussy Riot and the Insider/Outsider Challenge to Post-Soviet Orthodoxy" (Shevzov 2014). 
how Alfeyev can logically equate such free expression with totalitarianism and oppression. Ironically, it is Alfeyev who appears to be countenancing state suppression of dissenting minority voices that offend the sensibilities of the majority. Accordingly, one can only conclude that Alfeyev believes Russia's legislation suppressing the kinds of billboards he laments seeing in England is "freedom," while allowing private citizens to fund such billboards is totalitarianism.

\section{Validation and Admonition from Secularization Theorists}

"Historically speaking, Christianity has been its own gravedigger" (Berger 1990, p. 129). Berger's socio-historical reworking of Nietzsche's proclamation that "God is dead, and we have killed him," is no less ominous nor is it any less insightful than the philosopher's earth-shaking assessment of Euro-American culture. Of crucial importance here is that the core issues identified above in ROCOR's epistle and Alfeyev's address bear within themselves all of the elements through which Christianity dug its own grave. The danger, in short, is that a resurgent Russian Orthodoxy appears poised to become its own gravedigger. Perhaps of even greater importance is that the concerns of ROCOR and Alfeyev also miss the elements Jose Casanova has identified as central to the revitalization of Christianity in the contemporary context.

Let us recapitulate five essential points drawn from the ROCOR epistle and the Alfeyev address. First, ROCOR has consistently conflated political martyrdom with martyrdom for the faith, which is directly related to their conflation of church and state. Second, ROCOR's absolutist insistence on symphonia revolves around its accusation that "the educated classes in Russia, raised in so-called 'Westernizing' traditions, pushed Russia with almost suicidal relentlessness into the abyss." Third, Alfeyev's positions indicate that increase in state power is positive so long as it corresponds with an increase in the power of the Church to enforce its morality as socially normative. Fourth, Alfeyev's stance inherently privileges the feelings of the majority within a given population, thereby implicitly endorsing the suppression and marginalization of dissenting or minority voices. Fifth, both ROCOR and Alfeyev express significant concern about the hegemony Western liberal democracies hold and the aggressiveness by which they impose their will both on their own populaces and on other cultures.

Of these five points, the first four all illustrate characteristics of how Christianity became its "own gravedigger." While Berger identifies a number of complex factors that fuel secularization in a way that renders religion increasingly irrelevant, the most pertinent ones to explore here are the unintended consequences that result from Christianity's conception of history as linear and, moreover, as a story of progress (Berger 1990, pp. 117-19). That is, Christianity gave the world a set of ethics and values, along with a conception of history that presupposes progress towards greater and greater actualization of these ethics and values. For example, the Christian Scriptures preach universal and unconditional love (e.g., 1 Cor 13), a duty to care for the poor (e.g., James 2-5), and a radically egalitarian message of the equality of all before God (e.g., Galatians 3). Because of its cultural ascendancy it transformed the values of Roman Empire and thus the European culture descended from it. Once these values are taken as "self-evident" within a culture, what then happens to the various churches when they no longer promote progress in these areas, and indeed often become obstacles to such progress? What happens when Christendom begins to stand in the way of universal and unconditional love? What happens when it merges with political and economic powers that ignore or even villainize the poor? What happens when Christianity manifests itself as deeply hierarchical and patriarchal instead of radically egalitarian?

The answer, to repeat the phrase again, is that through these instances "Christianity becomes its own gravedigger." As Berger puts it, the result is that the "consciousness of Western man" is thrown into a crisis that inaugurates "an age of revolution" (Berger 1990, p. 79). More specifically, to quote Albert Camus, humanity "launches the essential undertaking of rebellion, which is that of replacing the reign of grace with the reign of justice" (Camus 1956, p. 56). The secular revolutionary, who has internalized the values laid down by Christianity, begins to oppose the Church for standing in the way of progress in love, in care for the poor, in promoting egalitarianism, etc. Put differently, 
because Christianity made promises that it now refuses to keep, it appears instead as institutionalized injustice - an agent of hate, a defender of the rich and legitimizer of wealth accumulation, and an upholder of oppressive hierarchical systems. In doing so, Christians largely become guardians of the status quo and "traditional values," especially sexual norms, while secular humanists paradoxically become those most passionately committed to social progress that actualizes the core proclamations of the Gospel. When such a state of affairs has developed, the bulk of Christianity renders itself largely irrelevant at best, and an enemy to be opposed and overthrown at its worst ${ }^{16}$.

If we consult the work of Charles Taylor and Mikhail Epstein, we find evidence these processes may already be beginning to occur in Russia, in ways far more subtle than the "Pussy Riot Incident" or organized protests against both the ROC and the Putin government. Taylor, following Epstein, argues that secularization in Russia is most prevalent not in such overtly rebellious movements, but in the large number of Russian people who are embracing "minimal religion" instead of devout practice of Russian Orthodox Christianity. "Minimal religion" correlates rather well to the growing number of people in Western Europe and North America who identify as "spiritual but not religious" (Taylor 2007, p. 535). Elaborating on Epstein's groundbreaking study, Taylor states, “'Minimal religion' is a spirituality lived in one's immediate circle, with family and friends, rather than in churches, one especially aware of the particular, both in individual human beings, and in the places and things which surround us. In response to the universalist concern for the "distant one" stressed in Marxist communism, it seeks to honor the 'image and likeness of God' in the particular people who share our lives" (Taylor 2007, p. 534). In other words, a significant portion of the Russian populace is recognizing the common cultural values that were shared both by their Russian Orthodox Church and by the Marxist Soviet government. At the same time, they retain a certain independence and individualism because they recognize both of these institutions as having ultimately betrayed their own ideals. In sum, if Taylor and Epstein are correct about the rising prevalence of "minimal religion" in Russia, it would appear that the Berger (and Camus) thesis is unfolding in contemporary Russia as significant portions of the populace have accepted the key values of Christianity and Marxism, while becoming suspicious of both the ROC and the Russian state's interest in embodying these values ${ }^{17}$.

Is there then any way for the Russian Orthodox Church and other organized religious institutions to remain relevant and even flourish in the contemporary world? Jose Casanova's landmark Public Religions in the Modern World argues that the answer, "on the basis of ... empirical evidence," is "an unconditional yes" (Casanova 1994, p. 38). In Casanova's reading, because Western liberal democracies themselves grew out of Enlightenment appropriation of the core Christian values mentioned above, especially egalitarianism, they are representative of the kind of secularizing revolution for which Berger's theories account. However, Casanova also agrees with fellow secularization theorist Talal Asad ${ }^{18}$, as well as with ROCOR and Alfeyev, that Western liberal democracies have in turn betrayed these same ideals in deeply imperialistic and hegemonic ways. As Casanova incisively puts it, "the two dynamos of modernity, the capitalist market and the administrative state, continue their self-propelled march toward a world system, wrecking and challenging every pre-modern tradition and life form that stands in their way" (Casanova 1994, p. 234). According to Casanova, this development has opened up a renewed space for religious vitality in

16 Nevertheless, it is important not to confuse Christian defense of traditional values, with "fundamentalism" or "extremism." For an illuminating exploration of the differences between these positions, and, moreover, how they are playing out in contemporary Russia, see "Postsecular Conflicts and the Global Struggle for Traditional Values" (Stoeckl 2016).

17 Hard statistics on what Epstein and Taylor describe as "minimal religion" and its affinities with both Russian Orthodox Christianity and Soviet Communism are difficult to ascertain. A number of recent Pew research studies appear to support their assertions, however. See, for example, Epstein's "Minimal Religion" and "Post-Atheism: From Apophatic Theology to 'Minimal Religion'" in Russian Postmodernism (Epstein 1999), and compare with two Pew surveys and the conclusions drawn from them (Diamant 2017; Masci 2017).

18 See, for example, Asad's Formations of the Secular (Asad 2003) for a similar line of argumentation that critiques on Western liberal democracies and their attempts to unilaterally enforce Western constructions of secularity on predominantly Islamic cultures. 
a modern, secular context that does not attempt to "undo" secularization and return to a merger of religious and state institutions.

The dialectical mechanism that Casanova identifies as opening up this renewed space for religious vitality is both complex and straightforward. He explains:

A mutually reinforcing dynamic of recognition and rapprochement between religion and modernity has taken place, bringing to a close the conflictive cycles opened up by the Enlightenment critique of religion. On the one hand, the critical recognition of the dialectics of enlightenment and the postmodern self-limitation placed upon the rationalist project of secular redemption have led to a rediscovery of the validity claims of religion and to a recognition of the positive role of the Catholic church in setting limits to the absolutist tendencies of the modern state, whether in its Polish communist variant or in its Latin American "national security" variant (Casanova 1994, p. 62).

As proof of this thesis, Casanova engages in five case studies, three of which focus on how in Spain, Poland, and Brazil, the Roman Catholic Church transitioned away from state-sponsorship and participation in national oligarchical structures to supporting instead egalitarian movements, labor movements, and economic justice movements. That is, in each case, the Roman Catholic Church divested itself of formal power and began to take a stance against corporate and state power on behalf of those who were oppressed, suffering, or disenfranchised. In a nutshell, the Catholic Church began to actively promote the very values that the state was (ideally) supposed to uphold and yet had betrayed. What was the result? In each case, the Roman Catholic Church experienced a significant resurgence in the respect of the populace at large (amongst both Catholics and non-Catholics), as well as an increase in regular attendance at religious services (Casanova 1994, pp. 75-134). The great irony is that "it was this voluntary 'disestablishment' of Catholicism, this change of self-identity, which permitted the Catholic church to play an active role in processes of democratization from Spain to Poland, from Brazil to the Philippines" (Casanova 1994, p. 62). As the saying goes, "turnabout is fair play." When and where nation-states based on Enlightenment ideology were democratizing forces that broke down oppressive power structures, they gained greater credibility than religious institutions. Now that liberal nation-states and their collusion with oligarchic corporate forces have become increasingly oppressive, religious movements that stand against these powers as democratizing forces regain their credibility against the state.

Let us return now to the first four points gleaned from ROCOR's epistle and Alfeyev's address and analyze why, if Berger and Casanova are correct, the ROC may be unwittingly digging its own grave. As noted, ROCOR has conflated political martyrdom with martyrdom for the faith. If Tsar Nicholas (Romanov) II's death is martyric in the same fashion that St. Elizabeth Romanov's is, a perfect opportunity for the ROC to champion the Church as defender of the poor and oppressed is lost. St. Elizabeth divested herself from her noble status and worked tirelessly amongst the poor-and yet was killed by the Bolsheviks anyway. She is a powerful and enduring symbol of how a person living out the Gospel can actualize human liberation more effectively than either a Tsarist state or a Marxist one. By elevating Tsar Nicholas to the same status, this symbol is all but neutralized, and the ROC is re-enshrined as the church of the powerful and the elite.

Furthermore, ROCOR blames the revolution on the apostasy of "the educated classes in Russia, raised in so-called 'Westernizing' traditions." But why did they apostatize in the first place? Was it not for the very reasons that Berger and Casanova identify, namely, that the ROC had arguably betrayed the Gospel through its failure to oppose an oppressive state that the Bolsheviks arose as a this-worldly "messianism" bent on actualizing the promises of the Gospel in this world and not deferring it to an afterlife? Third, Alfeyev's endorsement of using state power to combat Western sexual libertinism, while remaining silent on the state's duty to promote equality and uplift the destitute, likewise suggests a bleak future for the vitality of the ROC in Russian culture. Finally, Alfeyev's stance privileges the feelings of the majority within a given population, and endorses the suppression and marginalization of dissenting or minority voices. Such a posture may "play well" in the short run, but is virtually 
guaranteed to replicate the "apostasy of the educated classes," which, in turn, will have a trickle-down effect to Russian society more broadly.

\section{Conclusion: Or, How Not to Dig Our Own Graves}

What, then, is the best path forward? In my opinion, as both a philosopher of religion and Eastern Orthodox theologian (and minister), I believe the answer lies in the title of this present collection of essays, Inward Being and Outward Identity. Only if the ROC, and the Orthodox Churches strive to come to a place where our inward ideals (the Gospel itself) and outward manifestations are one and the same will we flourish and remain vibrant in a secular world. Only if the Church promotes Christ's unconditional love and takes a consistent stand for the oppressed and marginalized in the face of increasing state power, whether this be in Western liberal democracies or in Russia and the former Soviet-bloc countries, will it overflow with the culturally transformative power of the Gospel. For this reason, I have not yet discussed the fifth point stressed by both ROCOR and Alfeyev, namely, their desire to resist the hegemony Western liberal democracies currently possess and the aggressiveness by which they impose their collective will both on their own populaces and on other cultures.

This final point sheds light on at least one reason why the ROC and the Russian government currently have high approval ratings with the Russian populace. As secularization theorists like Berger and Talal Asad note, "While secularization may be viewed as a global phenomenon of modern societies, it is not uniformly distributed within them" (Berger 1990, p. 108) ${ }^{19}$. For both Berger and Asad, secularization and its manifestations will differ greatly depending on whether they occur in a Protestant, Catholic, Orthodox, Sunni, Shia, Hindu, or Buddhist context, as the secular as such will always retain many of the religious and cultural values even after these values no longer exert official dominance over state institutions and popular culture. Accordingly, when, for example, French post-Catholic understandings of "the secular" are imposed on a largely Muslim populace in Algeria, any resulting backlash is not against secularization itself, but against the oppression that results from colonizing another culture with an alien construction of what counts as genuinely "modern" and "secular." In this regard, the ROC's resistance to "Westernization" can be read as a way in which the ROC is functioning as a democratizing force in a manner that would fall under the umbrella of what Casanova describes. The crucial issue, then, is that this does not become the sole manner in which the ROC enacts resistance to oppression and promotes human freedom.

Curiously enough, the broader answer lies embedded within Alfeyev's address, although it is unfortunately left undeveloped, unexplored, and, ultimately, contradicted by the rest of Alfeyev's conclusions. For Alfeyev contends that more than any other religion or ideology, Christianity possesses a "reverential attitude towards freedom" that has the power to resist "totalitarian" and "despotic" states. Thus he quotes "the great Russian philosopher Nikolai Berdyaev [who] said that 'freedom, above all freedom, is the soul of Christian philosophy and this is what cannot be granted by any other abstract and rationalistic philosophy'" (Alfeyev 2014). Alfeyev thus agrees with Berdyaev on the level of "inward being" but remains, wittingly or unwittingly, an opponent of Berdyaev in terms of "outward identity." This is because Berdyaev, while he endorsed "theocracy," did so as an avowed anarchist, not as a believer in Tsarism, monarchy, democracy, or any other state power. As Berdyaev himself states:

If a religious rebirth be possible, only then on this soil will there be the revealing of the religious meaning of secular culture and earthly liberation, the revealing of the truth about mankind. For the new religious consciousness the declaration of the will of God is together with this a declaration of the rights of man, a revealing of the Divine within mankind ... This will be the victory of the true theocracy, whether over a false democratism - the apotheosis of the quantitative collectivity of human wills, or so also over

19 See also Formations of the Secular (Asad 2003, pp. 1-20, 181-204). 
the false theocraticism—all that apotheosis of the human will within Caesaropapism or Papocaesarism. Christ cannot have human vicarage in the person of the tsar or high-priest. $\mathrm{He}-$ is Himself the Tsar and High-Priest, and He will reign in the world. 'Thy Kingdom come, Thy Will be done on earth, as it is in Heaven" (Berdyaev 1907).

Berdyaev believed strongly in the transformation of culture through the message of the Gospel, but because the message of the Gospel is about human freedom and divine indwelling of the human being, state coercion has no role to play in it, whether it be the coercion of the masses in a "liberal democratic" state, or a coercion by a monarch in an imperial or dictatorial state. For Berdyaev, Christianity is a community of people freely living in solidarity with each other and the will of God, and accordingly the state literally has no role to play in promotion of the Gospel. Berdyaev's views also align seamlessly with Casanova's. The key to Christianity's rebirth lies not in having "toleration" or "symphonia" from a governmental power, but in being the force that is defending and manifesting "the rights of man."

Understood this way, the "golden age" of Christianity, if we are going to audaciously label any age as such, ought to be understood as its first three centuries, when Christians freely associated and influenced society by their genuine love of each other and willingness to be persecuted unto death to bear witness to what Berdyaev calls "the declaration of the rights of man." The martyrs did not "buy" a later golden age with their blood as Alfeyev asserts; theirs was the age in which Christians were most free to reenact the life, the teachings, and the death of Jesus. Christianity is a free association of human community. Nations are not. As the American historian Howard Zinn put it:

Nations are not communities and never have been. The history of any country, presented as the history of a family, conceals fierce conflicts of interest (sometimes exploding, most often repressed) between conquerors and conquered, masters and slaves, capitalists and workers, dominators and dominated in race and sex. And in such a world of conflict, a world of victims and executioners, it is the job of thinking people, as Albert Camus suggested, not to be on the side of the executioners (Zinn 2009, p. 10).

If one agrees with Zinn, we might reformulate this phrase (again in a way that Casanova would approve of) to state, "it is the unequivocal duty of Christians not to be on the side of the executioners." If we turn to the original Camus quote that Zinn has paraphrased, we will find a fitting conclusion to this essay, for Camus's exact words are that if we think in a manner "free of fear as well as pretension, we may be able to help create the conditions for a just philosophy and for a provisional accord among those of us unwilling to be either victims or executioners" (Camus 2006, p. 261). It is fear that drives religious figures to again and again seek the support of the state or symphonia with it. But no one who reads the lives of St. Stephen, St. Ignatius of Antioch, St. Perpetua, St. Polycarp, St. Elizabeth the New Martyr, and the like will find fearful victims. Rather, it is the martyrs who again and again assert that it is they who hold true power and freedom, while their executioners are the actual victims of the state's directives. If Orthodoxy seeks not to become "its own gravedigger," all of us in the Church would do well to stand with the martyrs and with Camus, unwilling to be either victim or executioner.

Conflicts of Interest: The author declares no conflict of interest.

\section{References}

Alfeyev, Hilarion (Metropolitan Hilarion). 2014. The Theology of Freedom: Christianity and Secular Power from the Edict of Milan to the Present. Available online: https:/ / mospat.ru/en/2014/10/18/news109757/ (accessed on 3 May 2017).

Altizer, Thomas J. J. 2002. The New Gospel of Christian Atheism. Aurora: Davies Group.

Asad, Talal. 2003. Formations of the Secular: Christianity, Islam, Modernity. Stanford: Stanford University Press.

Berdyaev, Nicholas (Nikolai). 1907. Nihilism on a Religious Soil. Translated by Fr. S. Janos. Berdyaev Online Library, May 6. Available online: http:/ / www.berdyaev.com/berdiaev/berd_lib/1907_135_4.html (accessed on 3 May 2017). 
Berdyaev, Nicholas (Nikolai). 1949. Political Testament. Translated by E. Lampert. World Review Spring: 32-37, 80. Berger, Peter. 1990. The Sacred Canopy: Elements of a Sociological Theory of Religion. New York: Anchor Books.

Bryanski, Gleb. 2012. Russian Patriarch Calls Putin Era "Miracle of God." Reuters, February 9. Available online: http:/ / uk.reuters.com/article/uk-russia-putin-religion-idUKTRE81722Y20120208 (accessed on 3 May 2017).

Camus, Albert. 1956. The Rebel. New York: Vintage Books.

Camus, Albert. 2006. Neither Victims nor Executioners. In Camus at Combat: Writing 1944-1947. Translated by Arthur Goldhammer. Princeton: Princeton University Press, pp. 256-76.

Casanova, Jose. 1994. Public Religions in the Modern World. Chicago: University of Chicago Press.

Chidester, David. 2000. Christianity: A Global History. New York: HarperCollins.

Chomsky, Noam. 2003. Hegemony or Survival: America's Quest for Global Dominance (American Empire Project). New York: Henry Holt.

Chomsky, Noam, and Andre Vltcheck. 2013. On Western Terrorism: From Hiroshima to Drone Warfare. New York: Palgrave MacMillan.

Cox, Harvey. 2013. The Secular City: Secularization and Urbanization in Theological Perspective. Princeton: Princeton University Press.

Demacopoulos George E., and Aristotle Papanikolaou, eds. 2016. Christianity, Democracy, and the Shadow of Constantine. New York: Fordham University Press.

Denysenko, Nicholas. 2013. An Appeal to Mary: An Analysis of Pussy Riot's Punk Performance in Moscow. Journal of the American Academy of Religion 81: 1061-92. [CrossRef]

Diamant, Jeff. 2017. Orthodox Christians in Central and Eastern Europe favor strong role for Russia in geopolitics, religion. Pew Research Center, May 11. Available online: http://www.pewresearch.org/fact-tank/2017/ 05/11/orthodox-christians-in-central-and-eastern-europe-favor-strong-role-for-russia-in-geopoliticsreligion/ (accessed on 1 August 2017).

Edict of Milan. 313. Galerius and Constantine: Edicts of Toleration 311/313. Translated by University of Pennsylvania Department of History. Available online: http://sourcebooks.fordham.edu/halsall/source/ edict-milan.asp (accessed on 3 May 2017).

Epstein, Mikhail. 1999. "Minimal Religion”, and "Post-Atheism: From Apophatic Theology to 'Minimal Religion.'”. In Russian Postmodernism: New Perspectives in Post-Soviet Culture. Edited by Mikhaïl Epstein, Alexander Genis and Slobodanka Vladiv-Glover. New York and Oxford: Berghahn Books.

Eusebius. 2005. Orations in Praise of Constantine. Available online: http://www.ccel.org/ccel/schaff/npnf201.iv. viii.iii.html (accessed on 3 May 2017).

Grandin, Greg. 2007. Empire's Workshop: Latin America, the United States, and the Rise of the New Imperialism. New York: Henry Holt.

Greenwald, Glenn. 2014. No Place to Hide: Edward Snowden, the NSA, and the U.S. Surveillance State. New York: Henry Holt.

Gvosdev, Nikolas K. 2001. An Examination of Church-State Relations in the Byzantine and Russian Empires with an Emphasis on Ideology and Models of Interaction. Lewiston: Edwin Mellen.

Hobbes, Thomas. 1996. Leviathan. Cambridge: Cambridge University Press.

Hume, David. 1990. Dialogues Concerning Natural Religion. New York: Penguin Books.

Hume, David. 2016. Of the Original Contract. Baltimore: Laissez Faire Books.

Justinian, I. 1998. Medieval Sourcebook: Justinian: Novella 146: On Jews. Available online: http:/ / sourcebooks. fordham.edu/Halsall/source/novel146.asp (accessed on 3 May 2017).

Kant, Immanuel. 2016. Kant: Political Writings. Edited by H. S. Reiss. Translated by H. B. Nisbet. Cambridge: Cambridge University Press.

Klein, Naomi. 2008. The Shock Doctrine: The Rise of Disaster Capitalism. New York: Henry Holt.

Knox, Zoe. 2005. Russian Society and the Russian Church: Religion in Russia after Communism. New York: Routledge.

Locke, John. 1988. Two Treatises of Government. Cambridge: Cambridge University Press.

Marsh, Christopher. 2011. Religion and the State in Russia and China: Suppression, Survival, and Revival. London: Bloomsbury Academic.

Masci, David. 2017. In Russia, Nostalgia for Soviet Union and Positive Feelings about Stalin. Pew Research Center. June 29. Available online: http:/ / www.pewresearch.org/fact-tank/2017/06/29/in-russia-nostalgia-forsoviet-union-and-positive-feelings-about-stalin/ (accessed on 1 August 2017). 
Nietzsche, Friedrich. 1990. Twilight of the Idols and the Antichrist. Translated by R. J. Hollingdale. New York: Penguin.

Papkova, Irina. 2011. The Orthodox Church and Russian Politics. Oxford: Oxford University Press.

Rousseau, Jean-Jacques. 2009. Discourse on the Origin and Basis of Inequality among Men. Oxford: Oxford University Press.

Ryan, James. 2012. Lenin's Terror: The Ideological Origins of Early Soviet State Violence. London: Routledge.

Shevzov, Vera. 2014. Women on the Fault Lines of Faith: Pussy Riot and the Insider/Outsider Challenge to Post-Soviet Orthodoxy. Religion and Gender 4: 121-44. [CrossRef]

Stoeckl, Kristina. 2016. Postsecular Conflicts and the Global Struggle for Traditional Values. State, Religion, Church 3: $102-16$.

Stout, Jeffrey. 2004. Democracy and Tradition. Princeton: Princeton University Press.

Synod of Bishops. 2017. Epistle of the Synod of Bishops of the Russian Orthodox Church Outside of Russia on the 100th Anniversary of the Tragic Revolution in Russia and Beginning of the Godless Persecutions. Available online: http:/ / www.pravoslavie.ru/english/101826.htm (accessed on 3 May 2017).

Taylor, Charles. 2007. A Secular Age. Cambridge: Harvard University Press.

Theodosius, I. 1997. Medieval Sourcebook: Banning of Other Religions: Theodosian Code XVI.i.2. Available online: https: / / sourcebooks.fordham.edu/source/theodcodeXVI.html (accessed on 3 May 2017).

Tolczyk, Dariusz. 1999. See No Evil: Literary Cover-ups and Discoveries of the Soviet Camp Experience. New Haven: Yale University Press.

Vahanian, Gabriel. 2008. Praise of the Secular. Charlottesville: University of Virginia Press.

Vltchek, Andre. 2015. Exposing Lies of the Empire. Jakarta: PT Badak Merah Semesta.

Zezulin, Lena. 2017. ROCOR Commentary on the February Revolution: Blame the West and Link Putin to the Tsars. Public Orthodoxy. April 20. Available online: https://publicorthodoxy.org/2017/04/20/rocorfebruary-revolution/ (accessed on 1 August 2017).

Zinn, Howard. 2009. A People's History of the United States. New York: HarperCollins.

(C) 2017 by the author. Licensee MDPI, Basel, Switzerland. This article is an open access article distributed under the terms and conditions of the Creative Commons Attribution (CC BY) license (http:/ / creativecommons.org/licenses/by/4.0/). 